Columbia Law School

Scholarship Archive

1998

\title{
Why Ownership Matters? Entrepreneurship and the Restructuring of Enterprises in Central Europe
}

\author{
Roman Frydman \\ roman.frydman@nyu.edu \\ Marek P. Hessel \\ hessel@fordham.edu \\ Andrzej Rapaczynski \\ Columbia Law School, ar5@columbia.edu
}

Follow this and additional works at: https://scholarship.law.columbia.edu/faculty_scholarship

Part of the Business Organizations Law Commons, and the European Law Commons

\section{Recommended Citation}

Roman Frydman, Marek P. Hessel \& Andrzej Rapaczynski, Why Ownership Matters? Entrepreneurship and the Restructuring of Enterprises in Central Europe, COLUMBIA LAW SCHOOL, THE CENTER FOR LAW \& ECONOMIC STUdies WORKING PAPER No. 172 (1998).

Available at: https://scholarship.law.columbia.edu/faculty_scholarship/1194

This Working Paper is brought to you for free and open access by the Faculty Publications at Scholarship Archive. It has been accepted for inclusion in Faculty Scholarship by an authorized administrator of Scholarship Archive. For more information, please contact scholarshiparchive@law.columbia.edu. 


\author{
Columbia Law School \\ The Center for Law and Economic Studies \\ 435 West $116^{\text {th }}$ St. \\ New York, NY 10027-7201 \\ Working Paper No. 172
}

\title{
Why Ownership Matters? \\ Entrepreneurship and the Restructuring of Enterprises in Central Europe
}

Roman Frydman

New York University Dept. of Economics

\author{
Marek P. Hessell \\ Fordham University Graduate School of Business \\ Andrzej Rapaczynski \\ Columbia University School of Law \\ School of Law
}

This paper can be downloaded without charge from the Social Science Research Network electronic library at: http://papers.ssrn.com/paper.taf?abstract_id=194574

An index to the working papers in the Columbia Law

School Working Paper Series is located at: http://www.law.columbia.edu/lawed 


\title{
WHY OWNERSHIP MATTERS?
}

\section{Entrepreneurship and the Restructuring of Enterprises in Central Europe}

\author{
Roman Frydman, ${ }^{1}$ Marek Hessel, ${ }^{2}$ Andrzej Rapaczynski ${ }^{3}$ \\ April 1998
}

\footnotetext{
${ }^{1}$ Department of Economics, New York University, and Privatization Project

${ }^{2}$ Graduate School of Business, Fordham University, and Privatization Project

${ }^{3}$ Columbia University School of Law, and Privatization Project
} 


\section{Introduction}

There exists by now growing empirical evidence that ownership affects company performance. Much of it comes from studies of privatization. Megginson, Nash, and van Randenborgh (1994) document improvements in post-privatization performance of 61 large firms in 18 countries. La Porta and López-de-Silanes (1977) provide evidence from Mexico, while Frydman et al. (1999) and Pohl et al. (1997) examine medium-size and large firms, respectively, in Central and Eastern Europe. Earlier findings by Earle et al. (1994) and Barberis et al. (1996) provide evidence of the effectiveness of privatization of retail shops and other small businesses in Central Europe and Russia, respectively.

The difference between state and private ownership is not the only one that affects firm performance; different types of private owners also generate different returns. Morck, Shleifer, and Vishny (1988) present evidence that managerial ownership below certain levels improves performance (as measured by Tobin q), but is associated with lower performance at higher levels. Numerous studies have dealt with the impact of worker ownership on firm productivity, investment, capital raising ability, etc. (See Hansmann, 1996, for a review.) Frydman et al. (1999) provide evidence that firms privatized to different types of owners differ significantly in postprivatization performance, with especially pronounced differences between firms controlled by corporate insiders and outside investors.

Not only do firms owned by different owners perform differently, but also some aspects of firm performance are more affected than others by differences in ownership. Thus, Frydman et al. (1999) find that firms controlled by outsider owners outperform those owned by corporate insiders or the state in terms of their revenue performance, but that ownership does not appear to make a significant difference in terms of (labor and material) cost performance.

That ownership makes a difference is very important. But can we explain why? There are several types of explanations advanced in the literature. Some commentators focus on the difference between state- and privately-owned firms and attribute the inferior performance of state firms (in terms of the standard criterion of value maximization) to the fact that state officials are prone to impose on the management of state companies a variety of goals, such as minimization of layoffs, political patronage, or protecting other state firms' markets (Shleifer and Vishny, 1994). A 
similar change in the objective function of a firm may also be associated with some forms of private ownership: employees, for example, may be interested in minimizing layoffs, and be prepared to compromise, for this end, the value-maximization objective.

Other explanations focus on different levels of entrepreneurship that may be associated with different types of ownership, and thus on the readiness of firms with certain types of owners to accept higher levels of risk, their willingness to innovate, and the skills that allow them to accomplish better the objectives they pursue. In particular, some have argued that the success of firms with certain types of owners is due to a better incentive structure of persons charged with making business decisions. Others have attributed the same performance differences to the fact that firms with certain types of owners are controlled by people whose superior human capital allows them to achieve better results. (Barberis et al., 1996.)

In this paper, we present the results of empirical analyses of medium-size firms in three transition countries in Central Europe and seek to clarify the way ownership affects a firm's revenue and cost performance by focusing on behavioral differences among firms owned by the state, outside investors, and corporate insiders (managers and employees). In particular, we examine the restructuring activities undertaken by different types of firms from the point of view of the differences they may reveal with respect to the degree of entrepreneurship that may characterize firms with different types of owners.

Grosfeld and Roland (1997) hypothesized that firms with different types of owners may, when faced with new challenges, engage in different types of adaptive behavior, and they distinguished between "strategic" (revenue-oriented) and "defensive" (cost-oriented) restructuring. Interestingly, we found no significant differences in the frequency or general type of product restructuring engaged in by firms with different types of owners, indicating that the difference in the success rate of different owners is not to be accounted for in terms of what their firms do: in fact, all of them attempt to revamp their product offerings by undertaking broadly the same types of measures, such as introducing new products, changing design or packaging, or improving quality by new production processes.

The relationship between restructuring and performance is, apparently, more complicated. Although engaging in specific forms of product restructuring id not a sufficient condition of 
success in improving performance, neither can success be achieved without extensive revamping of the firm's operations: we find that firms which do not restructure their products, whether owned by outsiders, insiders, or the state, do not experience significant improvements in revenue performance. But among the firms that do restructure, some - those owned by outsiders - tend to generate significantly higher revenues, while others do no not. What determines, therefore, the success of some firms, and not others, in their restructuring efforts seems to lie more in who does it, and how, rather than in what they are doing.

This should not be surprising, if - as we shall argue - it is the degree of entrepreneurship that makes some firms more successful than others. The very nature of entrepreneurship is likely to lie in factors - such as a talent for spotting opportunities not seen by others, a willingness and ability to act on often idiosyncratic "hunches" and intuitions that cannot be easily communicated to others (but which ultimately turn out to be correct), and the ability to take risks in order to succeed - which do not lend themselves to being captured by the "what" of an activity. Indeed, were we able to specify some general, objectively reproducible criteria of what an entrepreneur does (such as the frequency of restructuring or types of product changes), the advantages of entrepreneurship would disappear, to be replaced by a system of rules that could be followed by anyone. Only if such rules do not exist, can ownership be truly indispensable.

We proceed, therefore, to analyze the relationship between ownership and entrepreneurship by testing the hypothesis (advanced in Barberis et al.,1996) that firms controlled by certain owners are more successful in restructuring their products (and consequently outperforming other firms in terms of their sales) because the quality of the human capital of their decision makers is simply higher than in other firms. Although there are reasons to believe that in a developed society, firms with certain types of owners might, over time, attract better managers than others, there is no evidence of this in our sample (perhaps because the managerial labor market has not yet had enough time to operate). Moreover, we find evidence in our data that the performance differences we observe among firms with different types of owners are not primarily due to differences in the quality of the human capital of their decision makers, and that firms in which the principal decision makers remain unchanged experience significant changes in their performance upon a change of owners. 
We therefore argue in favor of linking the better performance of firms with certain types of owners to the incentive effects of ownership. Although entrepreneurship is clearly in part a matter of human ability - perhaps even largely innate ability - certain ownership arrangements appear to allow it better to thrive and manifest itself in performance. We associate this aspect of ownership with different attitudes toward risk and different degrees of accountability that various control structures impose on the decision makers responsible for major restructuring. We then test this hypothesis by examining the variance of the performance of firms with different types of ownership (which should reflect their ability and willingness to accept risk) and find significant differences among them. In particular - as expected - the performance of outsider-owned firms is characterized by significantly higher variance than that of the firms owned by either insiders or the state.

\section{The Data}

The present study is based on a survey of 506 manufacturing firms in the Czech Republic, Hungary, and Poland conducted in the fall of 1994. To avoid the special problems of the industrial "dinosaurs" of the communist era, the sample was drawn from mid-size firms employing between 100 and 1,500 persons; the median 1993 sales were just above US\$ 6 million. The firms were drawn randomly from the list provided by the Central Statistical Office in each country, but when a maximum of firms with a certain type of owners was reached, further firms with the same ownership type were excluded from the drawing. ${ }^{1}$ In this sense, the ownership composition of the sample may not reflect the composition of the parent populations.

Since we are interested in behavioral differences among firms that are similar in all respects but their ownership, we focus here on firms that were all state owned at the beginning of the sample period. We therefore eliminated from the original sample 88 private firms that were never state-owned. The ownership structure of 87 other firms was in doubt, and we excluded them

\footnotetext{
${ }^{1}$ We imposed this restriction to assure presence of firms with different types of owners. No deviations from random drawing turned out to be necessary in Hungary.
} 
from the subsample as well. ${ }^{2}$ Of the remaining 331 state and privatized firms, ${ }^{3} 87$ firms did not provide complete enough data to allow for an analysis of any aspect of their performance, ${ }^{4}$ and 29 firms provided unusable or dubious data. Thus, the largest available sample, used to evaluate revenue performance, consists of 215 firms, 90 of them state and 125 privatized.

In terms of country distribution, 36 percent of the firms were in the Czech Republic, 42 percent in Hungary, and the remaining 22 percent in Poland. The firms operated in both consumer (food and beverages, clothing, and furniture) and industrial (non-ferrous minerals, chemicals, textiles, and leather) goods sectors, with 58 percent of privatized firms and 48 percent of state firms in consumer goods sectors. Practically all state (90 percent) and privatized (93 percent) firms faced domestic or foreign competition for their products.

In the overwhelming majority of cases the privatized firms in our sample had a very concentrated structure of ownership ${ }^{5}$, allowing us to identify the firm's ownership type with that of its largest shareholder. ${ }^{6}$ Insiders (managerial or non-managerial employees) and foreign

${ }^{2} 60$ firms in Hungary listed ownership types which we could not classify as either state or private (primarily because of the presence of corporate entities with unknown ownership), and 1 firm did not provide the identity of the largest owner. We also excluded all (26) firms privatized through leasing. The nature of leasing in Poland and ESOPs in Hungary made it difficult for us to categorize unambiguously the leased firms according to their ownership, especially when they were not employee-owned. We verified, however, that the inclusion of these firms produced no significant changes in the results reported in this paper.

${ }^{3}$ By a privatized firm we mean an enterprise (partially or totally) privatized through a privatization of a predecessor state-owned company (or its part) in which the combined holdings of private parties give them a blocking power. We consider private parties to have blocking power if they control the percentage of votes formally sufficient to block major decisions at the general shareholder meeting. Note that this means that in some (15 percent) of the firms classified as privatized in this paper, the state remains a majority shareholder. But otherwise the high concentration of holdings in our sample makes the difference between blocking and majority power of little significance.

${ }^{4}$ We have no reason to believe that the incompleteness of data for certain firms introduces any systematic bias "in favor" or "against" any group of firms. The most common reason for incompleteness was lack of availability or an obvious misunderstanding of the meaning of certain questions.

5 Except for privatization funds, the average holdings of private parties in the position of the largest owner were majority holdings. All privatization funds were in the Czech Republic, where legal regulations at the time of the survey capped their individual holdings in any one firm at 20 percent. Even then, the combined holdings of different funds in a single firm typically added up to a majority.

${ }^{6}$ This opens the possibility that some of the differences between state and privatized firms we observe may be due to the particular type of concentrated ownership in our sample, and firms with smaller (and less active) owners may not behave in the same way. The owners' behavior may also be affected by the degree of the 
investors were the most frequent owners (each the largest shareholders in about 25 percent of privatized firms), followed by privatization funds ( 20 percent of privatized firms). Although division of ownership and management was the norm, the owners seem to be relatively active in monitoring their firms: almost all (94 percent) of the managers of privatized companies in the sample consult "regularly" (74 percent) or "occasionally" (20 percent) with their main shareholders. (Full distributions of sample firms by ownership type, country, size, and industrial sector in Appendix A.)

Table 1 presents the summary statistics of the annual rates of growth of revenues and (labor and material) costs per unit of revenues for the firms in our sample over the 1990-1993 period. The statistics clearly show the extent to which the early stages of the postcommunist transition were characterized by a downward pressure on revenues for all types of firms. The collapse of the COMECON market for the products of many postcommunist enterprises and the loss of other previously captive markets shrank the revenue base of most firms: in each year between 1990 and 1993, over 80 percent of state and over 64 percent of privatized firms lost revenues, with most of them losing over 25 of their sales in 1990-91 period alone. With the employment reductions and cost cutting often insufficient to catch up with the collapse of the sales, the pressure of the transition drove up the costs per unit of revenue. ${ }^{?}$

diversification of their investments. There are indications that most outsider owners of the firms in our sample are diversified.

\footnotetext{
${ }^{7}$ The decline in output and employment of state firms in the region has been discussed by, among others, Blanchard, Commander, and Coricelli [1994], Pinto and van Wijnbergen [1994], and Balcerowicz, Gray, and Hasi [1997]. Blanchard [1997] reviews the evidence and provides further references.
} 
Table 1: Data summaries (1990-1993)

\begin{tabular}{|c|c|c|c|c|c|}
\hline \multirow{2}{*}{$\begin{array}{l}\text { Average annual } \\
\text { rate of growth of }\end{array}$} & \multirow{2}{*}{$\begin{array}{l}\text { State } \\
\text { firms }\end{array}$} & \multicolumn{2}{|c|}{ Insider-owned firms } & \multicolumn{2}{|c|}{ Outsider-owned firms } \\
\hline & & Preprivatization & Postprivatization & Preprivatization & Post-privatization \\
\hline \multicolumn{6}{|l|}{ Revenue } \\
\hline Mean & -19.47 & -13.29 & -11.75 & -19.48 & -4.00 \\
\hline Standard deviation & 20.37 & 23.26 & 19.66 & 20.16 & 25.87 \\
\hline Minimum & -67.16 & -52.56 & -62.80 & -57.35 & -71.88 \\
\hline $25^{\text {th }}$ percentile & -32.67 & -25.50 & -25.05 & -34.93 & -21.48 \\
\hline Median & -21.82 & -15.42 & -11.75 & -18.50 & -6.33 \\
\hline $75^{\text {th }}$ percentile & -7.70 & -7.38 & -1.69 & -5.68 & 11.15 \\
\hline Maximum & 89.15 & 58.03 & 52.10 & 45.49 & 80.41 \\
\hline Number of observations & 224 & 34 & 41 & 62 & 151 \\
\hline \multicolumn{6}{|c|}{ Cost per unit of revenue } \\
\hline Mean & 3.73 & 3.90 & 6.61 & 0.95 & -2.90 \\
\hline Standard deviation & 14.93 & 13.84 & 23.13 & 18.32 & 18.68 \\
\hline Minimum & -26.69 & -16.21 & -57.77 & -35.98 & -55.90 \\
\hline $25^{\text {th }}$ percentile & -4.81 & -5.64 & -7.80 & -12.71 & -11.01 \\
\hline Median & 2.60 & 0.26 & 2.77 & 0.00 & -2.39 \\
\hline $75^{\text {th }}$ percentile & 11.02 & 11.31 & 21.10 & 15.27 & 5.04 \\
\hline Maximum & 59.89 & 41.72 & 59.42 & 41.69 & 58.22 \\
\hline Number of observations & 138 & 26 & 35 & 40 & 107 \\
\hline
\end{tabular}

\section{Ownership and Performance}

The effects of ownership on firm performance, which may be glimpsed from the statistics in Table 1, were analyzed in detail in Frydman et al. (1999). A breakdown of the results showed that the impact of different types of private owners on firm performance was too diverse to allow for meaningful generalizations at the level of a "privatized firm"; instead, the appropriate level of generality seemed to call for less inclusive groupings of "insider-owned" firms (i.e. those owned by employees and/or managers) and privatized firms owned by outside investors. Using fixed-effects panel regressions to estimate the impact of ownership type on firm performance, Frydman et al. (1999) found that outsider-owned privatized firms had significantly (nearly 10 percentage point) higher annual revenue growth than either state or insider-owned firms, but that no significant differences could be detected in terms of (labor or material) cost performance among any two groups of firms (see Table 2). The performance of state and insider-owned firms was statistically indistinguishable, both in terms of revenue and cost performance. 
TABLE 2

The effect of privatization for outsider- and insider-owned firms

\begin{tabular}{|c|c|c|}
\hline & $\begin{array}{l}\text { Annual rate of growth of } \\
\text { revenue }\end{array}$ & $\begin{array}{l}\text { Annual rate of growth of } \\
\text { cost per unit of revenue }\end{array}$ \\
\hline \multicolumn{3}{|l|}{ Privatization effects } \\
\hline Outsiders $^{1}$ & $\begin{array}{l}9.70^{*} \\
(3.64)\end{array}$ & $\begin{array}{l}-4.36 \\
(3.33)\end{array}$ \\
\hline Insiders $^{1}$ & $\begin{array}{l}0.68 \\
(5.28)\end{array}$ & $\begin{array}{l}1.12 \\
(4.45)\end{array}$ \\
\hline Test statistics for the model & $\begin{array}{c}\mathrm{n}=513, \mathrm{~F}=7.05^{*} \\
\quad \operatorname{adj} \mathrm{R}^{2}=0.13\end{array}$ & $\begin{array}{c}\mathrm{n}=347, \mathrm{~F}=5.27 * \\
\quad \operatorname{adj} \mathrm{R}^{2}=0.14\end{array}$ \\
\hline $\begin{array}{l}\text { Test statistics for the equality of } \\
\text { group effects }\end{array}$ & $\begin{array}{l}F=1.24 \\
p=0.29\end{array}$ & $\begin{array}{l}F=0.42 \\
p=0.66\end{array}$ \\
\hline
\end{tabular}

These results were controlled for differences in the macroeconomic environment of the three countries; they persisted across all industrial sectors in which the sample firms operated, and could not be attributed to possible performance "dips" in the years immediately preceding privatization. They were not driven by either a handful of well-performing firms or a few poorly performing firms (remaining virtually unchanged when the data set was trimmed at the $5^{\text {th }}$ and $95^{\text {th }}$ percentiles); and they were controlled for possible selection bias, both at the firm and the ownership-type level (Frydman et al., 1999). They thus provide robust evidence of a differential impact of ownership on firm performance, both in terms of a significantly better revenue performance of outsider-owned firms and the contrast between the effect of ownership on revenue and cost performance

\section{Ownership, Restructuring, and Entrepreneurship}

There are two basic ways in which firms can improve their overall performance: they may cut costs or increase their revenues. It has been suggested by Grosfeld and Roland (1996) that, in the environment of the postcommunist transition, there may be significant differences in the restructuring activities required to succeed in these two objectives. Grosfeld and Roland therefore 
distinguish between a "defensive" (cost-focused) and "strategic" (revenue-focused) restructuring, and they hypothesize that a firm's ownership may affect the type of restructuring the firm selects.

To cut costs, the notorious waste of the communist production system must be reduced, as must be the equally notorious overstaffing. Hoarding, made necessary by the constant shortages of the old regime, must give way to modern inventory management, assets unrelated to the main line of business must be shed, unprofitable production lines closed, materials must be used more rationally, often the use of floor space must be redesigned. Whatever else is involved in this type of "defensive" restructuring, it usually revolves around a relatively straightforward application of the established principles of management, and, faced with a hardening of the budget constraints, all firms, regardless of ownership, must engage in it or perish. The finding that ownership does not affect cost performance of firms in our sample in fact means that firms with different ownership types do not differ among themselves in terms of the success of their defensive restructuring.

There are reasons to believe, however, that the restructuring necessary to improve the revenue side of a firm's operation is of a different nature. Indeed, the skills required to improve sales of most companies in the transition environment - when the old markets have collapsed, imports have introduced overnight competition from the most advanced world producers, and buyers have become more careful and demanding - are not that different from those needed to start a new business: with some additional constraints (such as the existing labor force or the already available machinery), the post-communist firms must reinvent their products and find markets in which they can be sold. Discovering an area of a firm's comparative advantage calls for much more innovation and involves much greater uncertainty than eliminating the relatively obvious waste and laying off excess labor.

The difference between strategic and defensive restructuring is particularly stark in the circumstances of the postcommunist transition because the inefficiencies of the old enterprises are quite obvious, while their products are mostly worthless, and thus the company's future depends primarily on finding a new niche in the completely new environment of competitive markets. Nevertheless, the difference between cost and revenue restructuring probably has wider application and reflects principles of more universal significance. Although uncertainty is quite 
ubiquitous in corporate practice, the results of cost-related changes tend to be generally known to company insiders with a relatively higher degree of certainty than those related to revenue generation. The reason for this is that cost-cutting measures, while not always routine, are more a matter of managerial skill, based on techniques involving relatively predictable risks. Revenue generation, on the other hand, is inherently oriented toward anticipating future decisions of other agents (customers and competitors) and, for this reason, not only risky, but also subject to risks that are hard or impossible to compute on the basis of past history. ${ }^{8}$

At the root of the difference between cost and revenue restructuring may thus lie a difference between handling largely predictable (i.e. objectively recognizable) risks and dealing with unpredictable or radical uncertainty - something that might involve two different skills of great importance in every economy, and not just in the special circumstances of the postcommunist transition. While the first skill is one of managerial "science," i.e. a discipline based on generally applicable principles, the second involves the rather ill-defined combination of abilities often referred to as "entrepreneurship."

The nature of entrepreneurship is sometimes explained in terms of different attitudes toward risk (Knight, 1921) and in terms of the agents' ability to spot and pursue business opportunities (Hayek, 1948; Kirzner, 1979). But the concept remains somewhat vague and the relationship between entrepreneurship and ownership remains largely unexplored. In what follows we explore therefore the nature of entrepreneurship as manifested in the revenue restructuring of firms in the process of transition.

\footnotetext{
${ }^{8}$ This does not mean, of course, that there are no risks involved in cost cutting measures or that such risks are insignificant. What is being claimed here is that these risks, not involving predictions concerning the behavior of other parties, such as customers or competitors, tend to be better known and to involve less radical uncertainty.

${ }^{9}$ For a recent discussion of the importance of incorporating entrepreneurship into the neoclassical theory of the firm, its measurement, and significance for understanding the demise of the planned economies, see Rosen (1997).
} 


\section{Product Restructuring and Its Effectiveness}

We asked the chief production officers (CPOs) of our sample firms to list four product groups which contributed most to the firm's gross annual revenues in each sample year. ${ }^{10}$ We also asked them to identify changes in each of these groups introduced in the subsequent years, and to list all new product groups (regardless of their contribution to revenue) introduced during each year.

On the basis of these questions, we constructed a category of major product restructuring measures by grouping together the following: (i) introduction of new product groups; (ii) introduction of major new products within an existing product group; (iii) major changes in design or packaging of existing products; and (iv) introduction of major new production processes. The rationale behind this grouping was to isolate those changes in the firm's product portfolio that are aimed at gaining new markets or retaining the vanishing old ones, rather than straightforward cost-cutting operations. ${ }^{11}$ An introduction of new or improved products may or may not increase sales, but it is likely to require outlays that may contribute to a deterioration of a firm's cash flows and/or balance sheet position. ${ }^{12}$ Undertaking such innovations is more likely to involve a substantially higher degree of uncertainty and higher business risk than implementing most cost-reduction measures.

Table 3 presents summary measures of revenue restructuring activities among firms with different types of owners. Over the entire sample period, the proportion of firms that introduced at least one major product restructuring measure is very similar among all ownership groupings

\footnotetext{
${ }^{10}$ We defined a "product group" as "products which are produced using essentially the same type of equipment and production process, and do not differ substantially in the basic design. Examples of product groups include leather shoes, soaps, canned fruits, baked goods, beverages, etc."

${ }^{11}$ In the context of the transition economies, we treat the introduction of major new production process as primarily proxies for product quality improvements akin to the introduction of new products. The changes we attempted to capture with the concept of major product restructuring correspond to what Grosfeld and Roland (1997) label "strategic restructuring."

$1278 \%$ of the firms ( $83 \%$ of state and $74 \%$ of privatized) in our sample financed investments between 1990 and 1994 primarily from retained earnings. The level of long-term debt among the firms that introduced major product restructuring measures is also very low: the median is 3\% of 1993 revenues. Major product restructuring thus is very likely to have a direct impact on firm's cash position.
} 
(with no statistically significant differences between any two types of firms). ${ }^{13}$ To be sure, this statistic counts only changes implemented by privatized firms after they had been privatized (while for state firms changes throughout the sample period are recognized), and thus could hide a greater frequency of major product changes among privatized firms. But the average number of major product restructuring measures per firm per year - probably the most accurate measure of the frequency of major changes - also shows no significant differences among firms with different types of owners. ${ }^{14}$

Table 3: Major product restructuring measures undertaken by firms with different types of owners (1990-1993)

\begin{tabular}{|c|c|c|c|}
\hline & State firms & $\begin{array}{l}\text { Outsider-owned } \\
\text { firms }^{\mathrm{a}}\end{array}$ & $\begin{array}{l}\text { Insider-owned } \\
\text { firms }^{\mathrm{a}}\end{array}$ \\
\hline $\begin{array}{l}\text { Number (percentage) of firms with major } \\
\text { product restructuring measures }\end{array}$ & $69(77 \%)$ & $73(75 \%)$ & $18(60 \%)$ \\
\hline Average number of major changes ${ }^{c}$ & 3.51 & 1.87 & 2.30 \\
\hline Average number of years with major changes ${ }^{c}$ & 1.86 & 1.28 & 1.40 \\
\hline Average number of major changes per year ${ }^{c}$ & 1.17 & 1.00 & 1.27 \\
\hline
\end{tabular}

We also looked into patterns, as opposed to mere frequency, of product restructuring measures among firms with different types of owners, and, again, were unable to discover any significant differences that could explain differences in performance. The incidence of particular types of product restructuring measures (the introduction of new products or product groups, or

\footnotetext{
${ }^{13}$ That nearly 8 out of every 10 state firms introduced major product restructuring changes may be surprising, but it is consistent with previous reports of extensive restructuring among all types of firms, including state enterprises, in the transition environment (Pinto, Belka, and Krajewski, 1993).

${ }^{14}$ If anything, the number of major changes by the best performing (outsider-owned) firms is slightly lower, indicating perhaps that frequency of change may be to some extent a function of a failure, rather than success, of restructuring measures, and that firms that introduce successful changes may focus on consolidating their results, while those that make unsuccessful changes may try again. But overall, the frequency of the introduction of major product restructuring measures has no explanatory value with respect to revenue performance.
} 
changes in design, packaging, or production processes) was very similar in all ownership groupings, as was the occurrence of a large number of combinations of measures we tested.

The fact that differences in neither frequency nor pattern of major product restructuring explain differential revenue performance of firms with different types of owners raises the question of whether the measures of product restructuring we have chosen are indeed components of the "strategic restructuring" that is supposed to help improve the sales performance of firms in the postcommunist transition. We have tested therefore the impact of the activities we identified as "major product restructuring measures" on the revenue performance of firms in our sample by estimating a fixed-effects regression in which the firms were split according to their ownership type and variables were included to control for initial firm size and country-year effects. ${ }^{15}$ Since our revenue data are for calendar years, and privatization occurred, of course, at different times of the year, the effect of postprivatization restructuring in the year of privatization may be expected to be less (since it is given a shorter period of time to be felt) than when the firm operates as a private company for an entire year. As this could affect the averages (especially when the postprivatization period is generally short), we separated the year of privatization effects from the subsequent years' effects.

The results, reported in Table 4, indicate that the product restructuring measures we identified as potentially responsible for the superior revenue performance of outsider-owned privatized firms, as compared with their state- or insider-owned counterparts, are indeed an important factor in explaining their success, since outsider-controlled firms that did not restructure their products (in the sense we have identified) performed similarly to state and insider-owned firms, while those that did significantly outperformed their state- $(\mathrm{p}<.01)$ and insider-owned $(\mathrm{p}$ $<.05$ ) counterparts. ${ }^{16}$ The outsider-owned firms that restructured their products also performed

\footnotetext{
${ }^{15}$ We also tested, but do not report here, for a number of sectoral effects, and found none.

${ }^{16}$ In the firm fixed effects specification, the effect of major product restructuring changes in postprivatization years for outsider-owned firms retains its magnitude (15.33 vs 15.62 in group fixed effects specification) but with over twice the standard error (9.72 vs 4.43 ). The loss of precision is due to the fact that the firm fixed effect model uses up a lot of degrees of freedom, and, ceteris paribus, inflates the standard errors of all estimates. When a constant term is used instead of firm-level fixed effects, the OLS estimate of the restructuring effect has virtually the same magnitude as in the fixed effect model (15.80) but with much lower standard error (3.60).
} 
in subsequent years significantly better than those that did not $(\mathrm{p}<.05)$.

But if major product restructuring measures are a necessary condition of significant improvements in revenue performance, they are not sufficient, since essentially the same restructuring measures that allow outsider-owned firms to better their performance lead to no improvement in either state- or insider-owned firms - indeed, major product restructuring seems to make no difference in their case. ${ }^{17}$ In other words, it is an interaction of ownership and restructuring, rather than restructuring alone, strategic or not, that seems to be the key to a firm's ability to gain new markets and assure long-term survival.

${ }^{17}$ The evidence concerning the ineffectiveness of product restructuring by insider-dominated privatized firms should be treated with some caution. Since 9 of the 12 insider-owned firms that restructured their products were owned by workers, the estimate in Table 4 is based almost entirely on the performance of worker-owned firms. With only 3 manager-owned firms in the sample restructuring their products, we could not obtain meaningful estimates of the effectiveness of restructuring in these firms. (Note that the first row of Table 3 contains instances of restructuring occurring in 1994, for which no post-restructuring performance results are available, and which therefore could not be included in the regressions reported in Table 4.) The disadvantages of employee-ownership have been discussed extensively elsewhere (Hansmann, 1996), and our data suggest that, at least in the environment of the early postcommunist transition, those costs may completely neutralize the benefits of private ownership. The most relevant contrast in the post-restructuring performance of firms with different types of ownership is thus between state-owned firms and those privatized to outside owners. 
Why Ownership Matters, page 15

Table 4: The impact of major product restructuring on revenue growth

(Panel regressions, group fixed effects specification)

Annual rate of revenue growth

\begin{tabular}{|c|c|}
\hline \multicolumn{2}{|l|}{ State firms } \\
\hline With no major product restructuring & - \\
\hline With major product restructuring & $\begin{array}{l}-1.09 \\
(3.06)\end{array}$ \\
\hline \multicolumn{2}{|l|}{ Outsider-owned privatized firms ${ }^{1}$} \\
\hline Year of privatization & $\begin{array}{c}4.57 \\
(5.69)\end{array}$ \\
\hline Subsequent years & $\begin{array}{c}4.84 \\
(4.83)\end{array}$ \\
\hline \multicolumn{2}{|l|}{ With major product restructuring } \\
\hline Year of restructuring & $\begin{array}{c}10.13^{* *} \\
(5.25)\end{array}$ \\
\hline Subsequent years & $\begin{array}{c}15.62^{*} \\
(4.43)\end{array}$ \\
\hline \multicolumn{2}{|l|}{ Insider-owned privatized firms ${ }^{1}$} \\
\hline Year of privatization & $\begin{array}{l}-4.53 \\
(7.71)\end{array}$ \\
\hline Subsequent years & $\begin{array}{c}4.01 \\
(7.51)\end{array}$ \\
\hline \multicolumn{2}{|l|}{ With major product restructuring } \\
\hline Year of restructuring & $\begin{array}{l}-0.99 \\
(9.04)\end{array}$ \\
\hline Subsequent years & $\begin{array}{l}-2.21 \\
(8.09)\end{array}$ \\
\hline \multicolumn{2}{|l|}{ Country-year effects } \\
\hline \multicolumn{2}{|l|}{ Czech Republic } \\
\hline Year 2 & $\begin{array}{c}15.94^{*} \\
(4.77)\end{array}$ \\
\hline Year 3 & $\begin{array}{c}16.14^{*} \\
(4.65)\end{array}$ \\
\hline \multicolumn{2}{|l|}{ Hungary } \\
\hline Year 1 & $\begin{array}{c}3.52 \\
(4.52)\end{array}$ \\
\hline Year 2 & $\begin{array}{c}13.89^{*} \\
(4.47)\end{array}$ \\
\hline Year 3 & $\begin{array}{l}9.52 * \\
(4.54)\end{array}$ \\
\hline \multicolumn{2}{|l|}{ Poland } \\
\hline Year 1 & $\begin{array}{r}2.90 \\
(5.66)\end{array}$ \\
\hline Year 2 & $\begin{array}{c}10.06^{* *} \\
(5.44)\end{array}$ \\
\hline Year 3 & $\begin{array}{l}9.42 * * \\
(5.17)\end{array}$ \\
\hline Initial level of revenues & $\begin{array}{c}-0.17 * \\
(0.05)\end{array}$ \\
\hline Test statistics for the model & $\mathrm{n}=501 \quad \mathrm{~F}=4.88^{*}$, adj. $\mathrm{R}^{2}=0.13$ \\
\hline Test statistics for the equality of group effects & $F=0.62, p=0.54$ \\
\hline
\end{tabular}


Why Ownership Matters, page 16

From a theoretical point of view this may at first look like a disappointing result, since the concept of strategic restructuring does not seem, after all, to explain the advantages of ownership; quite the other way around, ownership seems to be, in the end, needed to explain why some firms succeed where others fail in their restructuring efforts. But, on reflection, the fact that the difference made by ownership cannot be reduced to an objectively ascertainable combination of restructuring measures or their frequency should not be surprising: if the advantages of ownership could be explained in this way, they would be ipso facto explained away, for it is difficult to see why the management of any firm, regardless of ownership, could not be charged with undertaking the same types of measures and deliver the same sort of performance.

The familiar theory of the firm as a nexus of contracts suggests that ownership is a solution to the problem of the inherent incompleteness of contracts, and thus probably substitutes for an unavailable system of objectively ascertainable rules of behavior (which could be used to bind contractually the agents responsible for company performance). This suggests, in turn, that an explanation of the role of ownership in corporate experience is not likely to lie in the what of corporate practice, like an explanation of what needs to be done, say, to put together the components of a machine (although here too a whole variety of complex skills is assumed). Rather, an account of ownership can be expected to resemble an account of what it means to be an artist or a sportsman: even if a number of things, such as training, perseverance, devotion, etc, without which artistry or sportsmanship are not possible, can be specified (and followed by all aspiring artists or sportsmen), there will always remain an element of "how," i.e., a tacit, perhaps even ineffable, skill or knowledge, that may be brought out and clarified to some extent, but which resists a reduction to an objectively available system of rules.

It is this element of at least partially tacit skill or knowledge, which gives the firms controlled by certain types of owners an advantage in improving revenue performance, that we identify with entrepreneurship. We have mentioned already that entrepreneurship has been associated with certain attitudes toward risk and an ability to spot and pursue business opportunities. We will attempt to clarify this concept further, but whatever the precise nature of the skill involved, we would like to examine first a recently advanced hypothesis concerning the contribution of ownership to the entrepreneurial behavior of firms and their managers. 


\section{Why Ownership Matters? The Human Capital Hypothesis}

Like every skill, entrepreneurship is likely to be, to some extent, a personal characteristic: some people may be naturally more prepared than others to accept risks or be able to spot business (or other) opportunities. Since these two characteristics are commonly seen as essential components of entrepreneurship, some people may be thus naturally more entrepreneurial than others. Indeed, it would not be surprising if this characteristic were, to a large extent, innate. But as with other skills or talents, people who are capable of entrepreneurship may not be able to develop or exercise it, unless the conditions are right. Thus, the incentive systems under which businessmen operate may also play an important role. Are the advantages of firms with certain types of owners related to the fact that people in control of them are simply more skillful at what they do than those in other firms, or are they related to a better incentive structure that some types of ownership provide? In recent literature, Barberis et al. (1996) have advocated the view that performance differences among firms with different types of ownership in the postcommunist environment are primarily attributable to fact that certain types of privatization "select owners and managers who are better at running firms efficiently," i.e. to the superior human capital of the persons in control of the better performing firms.

It is important to clarify what it would mean to deny that human capital improvements are the engine of success of the firms privatized to outsiders. First, it should be clear whose human capital is at issue. Most obviously, successful firms may have more skillful managers (whether or not they own equity) who run firms on a day-to-day basis. But privatization may also lead to a transfer of ownership to new persons whose superior skills as owners may perhaps be decisive for the firm's success. These skills may vary from the ability to choose managers (thus leading to higher average managerial human capital) to all kinds of other qualities an owner may exhibit in making basic corporate decisions.

In what follows, we will be mostly concerned with the relative importance of managerial human capital differences, as compared to different incentive structures of these corporate decision makers. To the extent owners themselves are managers (as was predominantly the case in the sample of shops and other small businesses examined by Barberis et al., 1996), or as far as differences in the owners' human capital manifest themselves in their choice of managers, our 
Why Ownership Matters, page 18 evidence concerning the importance of managerial human capital will also bear on the importance of the human capital of the owners. We will have no opportunity, however, to assess the importance of the quality of nonmanagerial owners' human capital insofar as these owners may be involved in a host of other corporate decisions where their skill may contribute to the firms' success. Although ownership is very concentrated in our sample of firms and there are reasons to believe that the nonmanagerial owners are consulted about major corporate decisions, we assume that the basic skills involved in running the firms in which management and ownership are separated lies with the managers, not the owners. To the extent the owners are not passive, we assume that their role, beyond that of choosing management, is limited to monitoring and the assumption of risk for major decisions proposed and executed by the management.

Second, it would be foolish to deny that entrepreneurship is largely a matter of personal skill: some people are surely better than others at making the risky, often idiosyncratic restructuring decisions allowing their firms to conquer new markets and increase their revenues. In the absence of such skills, no amount of incentives will make a firm really successful, much as no amount of promised rewards will make most people run a four-minute mile or become worldclass tennis players. Certainly, successful entrepreneurship is a matter of human capital in this sense.

But while human capital is a necessary condition of success, it would also be improbable if incentives did not matter: even the most skilled manager would not be likely to succeed, if success were punished, for example, rather than rewarded. Moreover, if different types of firms offer different incentives to people possessing certain types of skills (say, some reward entrepreneurship, while others put a premium on the ability to cut costs or run large organizations), one would expect managers with different types of skills to allocate themselves, over time, among different types of firms. As a result, to the extent that firms with different types of owners reward, say, different managerial skills, one would expect differences in the type of managerial human capital to track differences in ownership types, thus making it very difficult to separate the impact of incentives from the impact of managerial human capital improvements.

The question of incentives vs. human capital must, therefore, be one of their relative 
Why Ownership Matters, page 19

contribution. In particular, it would be interesting to find out, on the one hand, whether independently of the incentive structure they provide for their management, some owners are indeed better than others at picking better managers, and, on the other hand, whether different incentive structures associated with different types of ownership yield differences in performance even in the absence of human capital differences.

We explore these issues in two ways. First, although in a mature economy one may expect differences in human capital and incentive structures to go together, in a transition economy, especially in the early period, the market for managerial talent may not have had time to operate, and we may therefore be able to observe that ownership-related performance differences are not paralleled by differences in the characteristics of persons in control (which would indicate that other factors, in particular incentives provided by the firms for their management, ${ }^{18}$ are driving the differences in performance). Second, we examine the performance of firms in which the type of ownership has changed (as a result of privatization), but which continue to be managed by the same persons.

Our survey provides extensive information about the managers of both state and privatized firms, including their age, education, length of tenure, previous occupation, political beliefs, attitudes toward market economy and political changes since 1989, opinions about the role of the state and about the importance of various business objectives. All in all, despite substantial efforts, we have been unable to identify any systematic differences among enterprises with different types of owners. Since it has been often assumed (e.g. Barberis et al., 1996) that the old communist managers, who had been picked more for their ideological loyalty and their ability to manoeuver within the byzantine communist hierarchy, were less competent that the new people, appointed after the change of the regime, the data concerning managerial turnover, presented in Table 5, may be of special interest. What they show is that, unlike in Russia (where the small businesses studied by Barberis et al. were located), the managerial turnover in Central Europe has been high (though predictably somewhat lower in insider-controlled firms), and that

\footnotetext{
18 Barberis et al. (1996) take equity ownership as the only measure of incentives. We take a broader view, and treat all performance differences among firms with various types of ownership as due to different incentive structures, unless they can be accounted for in terms of better human capital. What these incentives actually are will be considered further in the next section.
} 
Why Ownership Matters, page 20

the rate of replacement of the old managers was not significantly higher in the better performing outsider-controlled privatized firms than in, say, the lagging state firms. It is also noteworthy that the proportion of promotions from within (which may have been more likely to pick up members of the old nomenklatura) among the firms privatized to outside investors is not significantly different from that in state firms. Nor are the managers of firms privatized to outsiders likely to be any younger than their counterparts in state and insider-controlled firms.

\section{Table 5: CEO's of state and privatized firms}

\begin{tabular}{|c|c|c|c|}
\hline & State firms & $\begin{array}{c}\text { Outsider-owned } \\
\text { firms } \\
\end{array}$ & $\begin{array}{c}\text { Insider-owned } \\
\text { firms } \\
\end{array}$ \\
\hline Number of firms & 72 & 85 & 29 \\
\hline Percentage of firms in which a new CEO was & $75 \%$ & $72 \%$ & $55 \%$ \\
\hline \multicolumn{4}{|l|}{ appointed during the $1990-94$ period } \\
\hline Of which promoted from within (\%) & $61 \%$ & $54 \%$ & $31 \%$ \\
\hline \multicolumn{4}{|l|}{ Percentage of privatized firms in which the present } \\
\hline $\mathrm{CEO}$ was appointed at or after privatization & - & $49 \%$ & $45 \%$ \\
\hline Average age of the present $\mathrm{CEO}$ & 46 & 47 & 49 \\
\hline \multicolumn{4}{|l|}{ Percentage of firms in which the present $\mathrm{CEO}$ is } \\
\hline less than 40 years old & $21 \%$ & $14 \%$ & $11 \%$ \\
\hline between 40 and 50 years old & $51 \%$ & $46 \%$ & $41 \%$ \\
\hline more than 50 years old & $28 \%$ & $40 \%$ & $48 \%$ \\
\hline
\end{tabular}

But perhaps the data on the rate of managerial turnover or the "profiles" of managers do not really capture the effectiveness of managerial changes in firms with different types of owners. Therefore, in order to examine more precisely the relative impact of ownership change and managerial turnover, we contrasted the performance of state-, insider-, and outsider-owned firms that did not change their management during the sample period with the pre- and post-change 
Why Ownership Matters, page 21

performance of firms in which the management did change. ${ }^{19}$ We also controlled for the countries in which the firms were located, macroeconomic changes, and initial firm size. The results are presented in Table 6. (In the left-hand side column, for the firms that did change their management during the sample period, only the first managerial change is recognized; in the right-hand side column, only the last managerial change is recognized.)

Even on the assumption that old managers were, by and large, incompetent and that managerial turnover, at least in the case of firms controlled by some types of owners, is among the most basic forms of postcommunist restructuring (Frydman, Pistor, and Rapaczynski, 1996; Barberis et al., 1996), performance comparisons of firms with new and old management are not likely to yield interesting results. If a given type of owner is expected to be able to identify bad managers and replace them with good ones, then, when the wave of pruning is completed (as, given the size of the turnover in the first three years, seems to be the case in our sample), the retained old managers are likely be the ones who are not incompetent and the firms they control should not perform worse than those in which the management did change. If, on the other hand, the owner is presumed to be unable to separate the wheat from the chaff, then the new managers should not be expected to be better than the old. The estimates reported in Table 6 support this conjecture. When the post-change performance of firms that changed management (i.e., those in which the owners presumably considered the performance of the incumbents unsatisfactory) is compared to that of firms which did not change management at all (i.e. to those in which the owners were presumably satisfied), no statistically significant difference is found, regardless of whether the first or the last managerial change is recognized (although the size of the coefficients indicates that the firms under new management may be somewhat more successful).

This does not mean, however, that managerial changes are not beneficial; just that their effect is not likely to be gauged by comparison with firms that did not change managers. The proper yardstick is the difference between pre- and post-change performance of firms that did

\footnotetext{
${ }^{19}$ For privatized firms, we have recognized managerial changes since privatization only (including any change occurring at the time the firm was privatized). This was done to focus on managerial choices made by the private owners, and exclude the possibly incompetent changes introduced by the state. Because the number of insider-owned firms that changed their managers was too small to allow for meaningful estimates, we included only those that did not change managers.
} 
Why Ownership Matters, page 22 change their management. According to this criterion, managerial change is probably beneficial in both state and outsider-controlled firms: although the post-change improvement is not significant when performance before and after the first managerial change is compared, it becomes significant for both types of firms when performance before and after the last change is compared (which allows the owners to change managers more than once if the first change does not bring the desired effects). ${ }^{20}$ But since the improvements from managerial turnover are significant and of similar magnitude in both state and outsider-controlled firms, they do not seem to be ownershiprelated. ${ }^{21}$ Whatever the impact of ownership, it must be felt elsewhere.

Comparisons of firms with different types of owners in which no managerial change took place since the fall of the communist regime are much more relevant - and telling - with respect to the question of the impact of ownership. Outsider-owned privatized firms that did not change their management still outperform their state- and insider-owned counterparts by significant margins - indeed, with respect to state-owned firms, the margin is roughly the same as that separating all outsider-owned privatized firms from all state firms (see supra, Table 2, and Frydman et al., 1999). Moreover, the superior performance of outsider-owned firms cannot be explained by any selection bias attributable to the fact that new private owners of these firms might have kept only good managers in place, and fired the bad ones (while perhaps the state was not equally skillful in its staffing decisions). Although such selection is likely to have occurred, it does not account for the superior performance of this group of privatized firms. Not only do panel regressions correct for such bias, but the group effects for the outsider-owned firms with no managerial change are virtually identical to those for state-owned firms. ${ }^{22}$ Since those effects gauge pre-privatization performance of privatized firms, the identity implies that prior to their privatization, the outsider-owned firms' performance was, on average, the same as that of their

${ }^{20}$ Again, data limitations do not allow us to gauge directly the post-change performance of the insidercontrolled firms.

21 This suggests, incidentally, that state firms' appointments under the new regime seem to be made primarily for business, rather than political, reasons.

${ }^{22}$ The group effects (not reported in Table 6) for state and outsider-owned firms with no managerial changes are, respectively, -23.08 (with a standard error of 5.17) and -24.74 (4.80) for the specification involving the first managerial change, and -23.39 (5.13) and -24.66 (4.76) for the specification involving the last managerial change. 
Why Ownership Matters, page 23 state-owned counterparts, and thus the managers in charge of them did not seem to stand out in any way prior to privatization. In the wake of privatization, however, even though the same managers remained in charge, the performance of their firms shot upwards in comparison to their state-owned counterparts, indicating that something other than differences in the quality of managerial human capital is primarily responsible for the differences in the performance.

In summary, then, differences in the quality of managerial human capital (or in the owners' skill in picking managers) are not likely to be responsible for the bulk of the performance differences between outsider-controlled privatized firms and their state- or insider-owned counterparts. Both state and privatized firms seem to appoint new managers in firms that lag in performance behind their peers, and in both types of firms such changes seem to lead to performance improvements. But the performance differentials of firms controlled by different types of owners are essentially independent of their (basically similar) managerial appointment policies: the outsider-owned firms, whether or not they change management, outperform state firms by similar margins in every category (including pre-change performance of firms that changed management). 
Table 6: The impact of managerial change on revenue growth

(Panel regression, group fixed effects specification)

Annual rate of revenue growth

First managerial Last managerial change recognized change recognized

State firms

With no managerial change

Prior to managerial change

$-4.47$

$-5.57$

Following managerial change

(4.28)

(3.95)

$-0.21$

3.08

(3.98)

$(4.25)$

Outsider-owned firms ${ }^{1}$

With no managerial change

$10.99 *$

11.30*

(4.50)

(4.46)

Prior to managerial change ${ }^{2}$

9.57

8.61

(6.26)

(5.94)

Following managerial change ${ }^{2}$

$15.67 *$

$18.51^{*}$

(5.88)

(6.03)

Insider-owned firms with no managerial change ${ }^{1}$

$-6.76$

$-6.38$

(6.17)

Czech Republic

Year 2

$17.33^{*}$

$17.13^{*}$

Year 3

$(4.88)$

(4.83)

$14.10^{*}$

$13.54 *$

(4.74)

$(4.70)$

Hungary

Year 1

4.19

4.52

(4.58)

(4.55)

Year 2

$13.80 *$

13.93*

$(4.57)$

(4.53)

Year 3

$10.62 *$

$10.13 *$

(4.61)

$(4.57)$

Poland

Year 1

1.39

3.19

(6.35)

(6.37)

Year 2

7.94

9.35

(5.85)

(5.81)

Year 3

8.99**

$9.11 * *$

(5.33)

(5.26)

Initial level of revenues

$-0.17 *$

$-0.17 *$

$(0.05)$

(0.05)

Test statistics for the model

$n=413, F=5.25 *$

$\mathrm{n}=413, \mathrm{~F}=5.69^{*}$

adj. $R^{2}=0.16$

adj. $R^{2}=0.17$

Test statistics for the equality of group effects

$\mathrm{F}=1.09, \mathrm{p}=0.35$

$\mathrm{F}=1.09, \mathrm{p}=0.35$

$*$ p \#0.05, ** p \# 0.10. Standard errors in parenthesis; significant coefficients on non-constant terms bold-faced. Revenues measured in constant local prices, initial revenues in US $\$ 1,000,000$ 's.

${ }^{1}$ A dummy variable set to 1 for the post-privatization performance of privatized firms where the given type of owner is the largest shareholder, 0 otherwise.

${ }^{2}$ Postprivatization periods only 


\section{Ownership and Entrepreneurship}

We argued that cost restructuring is primarily a matter of political will and managerial skills, while revenue generation requires entrepreneurship. Given the disappearance of previously captive markets for the inferior products of most firms, and the need of the postcommunist firms to "reinvent" themselves in product markets, strategic, revenue-oriented restructuring is inherently risky. ${ }^{23}$ This, in turn, makes two factors - which we see as the defining characteristics of entrepreneurship - of special importance: (1) the risk attitudes of the decision makers and (2) the constraints on the types of risks they can justify.

Both of these factors are related to incentives, and not just skills, and the incentives may depend on the ownership structure. Different payoffs faced by decision makers as an outcome of their decisions may be different in firms with different types of owners. Furthermore, regardless of the payoffs attached to different outcomes of particular decisions, the control structure of firms with different types of owners may impose different degrees of accountability, and this, in turn, may narrow the range of opportunities that managers of certain types of firms may be expected to pursue.

To begin with risk attitudes, the incentive structure induced by state ownership may be the most serious problem. Managers of state companies have their human capital heavily invested in their jobs and are thus exposed to the downside of risky projects, the failure of which may threaten their positions. On the other hand, they have only a limited expectation of participating in the potential upside of their decisions. As a result, they are likely to be generally risk averse, except when their firms are close to collapse (or when their jobs are already threatened because of the firm's inferior performance). In the latter case, managers of state firms may become risk prone because the downside of risky decisions becomes low to them (though not to the firm), while an even small chance of success promises to save their jobs. ${ }^{24}$

\footnotetext{
${ }^{23}$ To a large extent this is also true of market economies, particularly in periods of rapid demand changes when a firm's sales, far from being predictable of the basis of an exogenously given demand curve, depend on its ability to accommodate the largely unpredictable decisions of potential customers and consumers.

${ }^{24}$ The monitors of the managers of state firms have similar payoffs to the managers themselves. Like the managers, they derive limited benefits from the upside potential of risky decisions. On the downside, on the other hand, they are more likely to encounter political problems if the firms under their supervision go bankrupt (or require
} 
Why Ownership Matters, page 26

The incentives of the persons in control of insider-owned firms are somewhat more conducive to risk taking, as the upside of risky decisions may bring significant payoffs to the decision makers. But the problem of undiversified, firm-specific investment of both the human and financial capital of insider-owners is even more severe than in the case of state-owned firms, and may be a serious impediment to their willingness to bear the degree of risk required for success in the uncertain environment of the transition, except when the survival of the firm is already seriously endangered.

A different pattern of behavior may be expected in a firm owned by an outside investor. As we already noted, most of such firms in our sample have very concentrated ownership, and their owners are likely to be actively involved in ratifying major managerial decisions. ${ }^{25}$ At the same time, the most successful outsider-owned firms are controlled by institutions, such as privatization funds and foreign investors, who are also able to diversify their risks. They are thus both likely to be less risk averse and to impose their risk preferences on the managers in control of daily operations. Benefitting fully from the upside and paying for the downside of all decisions, these owners may be expected to maximize the value of the firm and will be prepared to ratify risky decisions, if the payoffs justify the risks. Unless the firm is heavily leveraged (as few privatized firms in our sample are; see footnote 21 above), these owners are also less likely to play Russian roulette with the firm when it is in financial difficulties, since the firm will have some residual value to them even if the business is not going well.

This pattern of risk attitudes is quite consistent with the different effectiveness of product restructuring measures we observe in our sample. If outsider-owned privatized firms engage in more risky types of restructuring, introducing radical changes and seizing the opportunities that present themselves, they can expect consistently higher returns than the firms controlled by more risk averse owners. Similarly, if the latter undertake the more risky forms of major product restructuring not in response to opportunities that arise when their firms do relatively better and

big bailouts) than if their "scrap" value is wasted (so that they are willing to undertake very risky projects to keep the firms afloat).

\footnotetext{
25 Recall that almost all (94 percent) of the managers of privatized companies in the sample consult "regularly" (74 percent) or "occasionally" (20 percent) with their main shareholders.
} 
Why Ownership Matters, page 27 can focus on changing their offerings, but when they are in distress and have to fight for survival, the results may be expected to be inferior.

The second, much less commonly observed, factor which we believe to be constitutive of entrepreneurship is related to the absence of constraints that a control structure may impose on the ability to make idiosyncratic decisions. Entrepreneurship is not a science: it does not proceed in accordance with well understood rules or a knowledge that can be objectively demonstrated (Kirzner, 1979). Instead, entrepreneurial decisions involve a large measure of ineffable skills and an often quite idiosyncratic evaluation of the situation that may be very difficult or impossible to explain to an outside observer. If the control structure of a firm requires, therefore, that the decision maker be able to justify what he does, this may severely restrict the opportunity set out of which a feasible projects must be chosen. The very feature of an entrepreneur's approach that allows him to succeed by breaking the mold of routine, rule-governed behavior, makes it very difficult for him to convey his "hunches" or "intuitions" to others whose views are within the prevailing consensus.

Again, the manager of a state firm or a bureaucrat charged with its supervision is at the greatest disadvantage here. It is the modus operandi of the state, for which there is ample justification in the political sphere, that officials must be accountable for what they do in terms of intersubjectively accessible principles. But in the context of business decisions, the rule of bureaucratic accountability is likely to restrict the possibility of entrepreneurship. An assignment of probabilities, for example, is required to assess the expected payoff from a creative project, such as a bet on a new product or a far-reaching design change. Under conditions of change and uncertainty, an objective (statistical) assignment of probabilities is likely to be extremely difficult or impossible. In such situations, an idiosyncratic, subjective assignment of probabilities to future events that turns out to be accurate after the fact is a paradigmatic example of entrepreneurship that allows some to increase their chances of success where others are most likely to fail.

But precisely because the assignment is subjective, it is difficult for a decision maker in a firm in which the principle of bureaucratic accountability is the rule to pursue such entrepreneurial projects. Even if a decision is right, the decision maker might be unable to clear it in advance with his monitors or, if he makes it on his own responsibility, explain it adequately if 
Why Ownership Matters, page 28 things go wrong (Hayek, 1948). Moreover, this difficulty is not due to any "deficiency" of the monitors to whom the decisions maker is accountable. Precisely because entrepreneurship involves idiosyncratic, subjective insights, the monitors who are unpersuaded by them are not only perfectly within their rights to reject them, but would be derelict in their duty if they accepted them against their own best judgment. Decisions that are worth making, therefore, including many product innovations that an owner, who need not account to anyone for what he does, will be likely to ratify, may for this very reason not be taken by a decision maker in a state enterprise.

The constraint of accountability is not an obstacle in a managerially-owned firm, but there are few of those in our sample of firms for which we have sufficiently complete product restructuring data. ${ }^{26}$ Most of the insider-dominated firms in our sample are worker-owned, and the problem of accountability is potentially serious here. The principals of worker-owned firms suffer from collective action problems, aggravated by conflicts of interest whenever the workforce is also not homogeneous (Hansmann, 1996). As a result, decisions are likely to require discussion and consensus, where entrepreneurship calls for a hierarchically imposed resolution with no accountability beyond the rewards and punishments delivered by the market.

By contrast, an outsider-owned firm with highly concentrated ownership apparently entails a control structure conducive to entrepreneurial decisions. Although the management of these firms is in control of day-to-day decisions, major risky projects need to be ratified by the owner. The owner, however, need not base his approval on objectively verifiable principles - it is enough that he trust his managers or have an independent sense of the appropriateness of the decision to be able to ratify it without further explanation and to assume all the risks it involves.

If the explanations proposed here to account for the superior effectiveness of product restructuring by outsider-owned firms is correct, the difference that ownership makes with respect to corporate performance should - according with our expectations - be observable not in the broad categories of restructuring undertaken by firms with different types of ownership, but rather

\footnotetext{
${ }^{26}$ Our sample of managerially-controlled firms for which revenue data is complete is sufficient, however, to show that these firms underperform their outsider-owned competitors. Thus, although the problem of accountability is not decisive here, the incentive structure of these firms, resulting in risk averseness and entrenchment (Morck, Shleifer, and Vishny, 1988), appears to be enough to depress their performance.
} 
Why Ownership Matters, page 29

in the different degrees of risk attached to various projects. This, in turn, suggests an empirical test capable of capturing the risk differentials of decisions made by firms with different types of owners: if the opportunity set that accountable decision makers are likely to face is narrower than that of the decision makers who need not explain their actions, and if outside owners are generally more likely to take justifiable risks than the insiders and state officials, the performance of firms with outside owners should be characterized not only by higher averages, but also by a significantly greater variance of outcomes than that of the other types of firms.

Figure 1 summarizes the differences in the variability of the annualized rates of revenue growth among the firms with different types of ownership which had introduced major product restructuring measures. The left part of Figure 1 shows the interquartile ranges of the annualized rates of revenue growth of firms with different ownership types, with the thick marks indicating the mean values. The rightward shift of the mean value of performance for outsider-owned firms is accompanied by a pronounced lengthening of the interquartile range, which (at 27.82) is nearly twice as large as that of state-owned (16.22) or insider-owned (15.50) firms .

\section{Figure 1 \\ Variability of annualized rates of revenue growth of privatized and state firm with major product changes}

Interquartile ranges

Variances
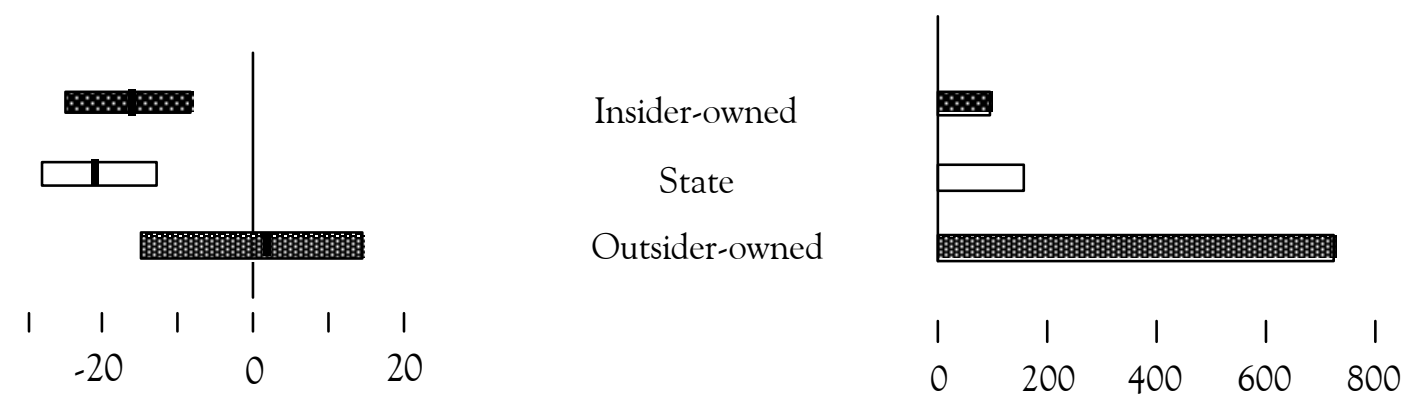
The differences in the variability of annual rates of revenue growth are captured by the variances of the corresponding distributions, shown in the right part of Figure 1: the higher average rates of revenue growth of firms privatized to outsiders are accompanied by significantly higher variances. The differences in both moments between outsider-owned and the other types of firms are significant at $\mathrm{p}$-values less than to 0.01 , regardless of the time period over which the performance of state firms is evaluated. By contrast, in the absence of major product changes the variance of annualized rates of revenue growth for outsider-owned firms is statistically indistinguishable from that for state- $(\mathrm{p}=0.27)$ or insider-owned $(\mathrm{p}=0.52)$ firms.

These results are consistent with our hypothesis that the superior results of product restructuring by firms privatized to outside owners are a function of their greater willingness to accept risks and their freedom to make decisions without having to justify them to employee owners or a hierarchy of state officials. Entrepreneurship certainly involves skills and abilities risk taking and nonaccountability pay off only when the decision maker uses them to good purpose. But entrepreneurial skills may also be inherently tied to certain types of ownership because only the incentives provided by such ownership may create the proper conditions for their exercise. 


\section{REFERENCES}

Why Ownership Matters, page 31

Ashenfelter, O. and D. Card, "Using the Longitudinal Structure of Earnings to Estimate the Effects of Training Programs," Review of Economics and Statistics, LXVII (1985), 648-660.

Balcerowicz, L., C. W. Gray, and I. Hashi, Exit Processes in Transition Economies: Downsizing, Workouts, and Liquidation (Budapest: Central European University Press, 1997).

Barberis, N., M. Boycko, A. Shleifer, and N. Tsukanova, "How Does Privatization Work? Evidence from the Russian Shops, Journal of Political Economy, 104 (1996), 764-790.

Blanchard, O., The Economics of Post-Communist Transition (Oxford: Oxford University Press, 1997).

Blanchard, O., S. Commander, and F. Coricelli, "Unemployment and Restructuring in Eastern Europe, in Commander, S. and F. Coricelli (eds.) Unemployment, Restructuring, and the Labor Market in Eastern Europe and Russia (Washington, D.C.: The World Bank, 1994).

Earle, J., R. Frydman, A. Rapaczynski, and J. Turkewitz, Small Privatization; The Transformation of Retail Trade and Consumer Services in the Czech Republic, Hungary, and Poland (Budapest: Central European University Press (in cooperation with Oxford University Press, 1994) .

Frydman, R., C.W. Gray, M. Hessel, and A. Rapaczynski, "When Does Privatization Work? The Impact of Private Ownership on Corporate Performance in the Transition Economies," Quarterly Journal of Economics, forthcoming 1999.

Frydman, R., K. Pistor, and A. Rapaczynski, "Investing in Insider-Dominated Firms: A Study of Russian Voucher Privatization Funds," in Frydman, Gray, and Rapaczynski (eds.) Corporate Governance in Central Europe and Russia. (Budapest: Central European University Press, 1996).

Frydman, R. and A. Rapaczynski, Privatization in Eastern Europe: Is the State Withering Away? (Budapest: Central European University Press, 1994).

Grogger J., "The Effects of Arrests on the Employment and Earnings of Young Men," Quarterly Journal of Economics, CX (1995), 51-71.

Grosfeld, I. and G. Roland, "Defensive and Strategic Restructuring in Central European Enterprises," Journal of Transforming Economies and Societies, III (1997), 21-46.

Groves, T., Y. Hong, J. McMillan, and B. Naughton, "Autonomy and Incentives in Chinese State Enterprises,” Quarterly Journal of Economics, CIX (1994), 183-209.

Hansmann, H., The Ownership of Enterprise (Cambridge, MA: Harvard University Press, 1996)

Heckman, J. J. and V. J. Hotz, "Choosing Among Alternative Nonexperimental Methods for Estimating the Impact of Social Programs: the Case of Manpower Training," Journal of American Statistical Association, LXXXIV (1989), 862-880.

Hayek, F., Individualism and Economic Order (Chicago: University of Chicago Press, 1948).

Kirzner, I., Perception, Opportunity, and Profit : Studies in the Theory of Entrepreneurship (Chicago: University of Chicago Press, 1979).

Knight, F., Risk, Uncertainty, and Profit (Boston: Houghton Mifflin, 1921).

La Porta, R. and F. López-de-Silanes, "The Benefits of Privatization: Evidence from Mexico," 
Working Paper 6215 (Cambridge, MA, NBER, October 1997).

Megginson, W. L., R. C., Nash, and M. van Randenborgh, "The Financial and Operating Performance of Newly Privatized Firms: An International Empirical Analysis, Journal of Finance, XLIX (1994), 403-52.

Morck, R., A. Shleifer, and R. Vishny, "Management Ownership and Market Valuation: An Empirical Analysis," 20 Journal of Financial Economics (1988), 293-315

Pinto, B., M. Belka, and S. Krajewski, "Transforming State Enterprises in Poland: Evidence on Adjustment By Manufacturing Firms," Brookings Papers on Economic Activity, 1(1993), 213-269.

Pinto, B., and S. van Wijnbergen, "Ownership and Corporate Control in Poland: Why State Firms Defied the Odds," Policy Research Working Paper 1308, The World Bank, Washington, D.C., 1994.

Pohl G., Anderson, R.E., Claessens, S. and S. Djankov, "Privatization and Restructuring in Central and Eastern Europe," Technical Paper No. 368 (Washington, D.C.: The World Bank, 1997) .

Rosen, S., "Austrian and Neo-Classical Economics: Any Gains from Trade?, Journal Of Economic Perspectives, 11 (1997), 139-152.

Shleifer, A., and R. Vishny, "Politicians and Firms, Quarterly Journal of Economics, CIX (1994): 995-1025. 


\section{Appendix A: Sample description}

\section{A1: Distributions of sample firms by year of privatization and firm size}

\begin{tabular}{|c|c|c|c|c|c|c|c|c|c|c|}
\hline & \multirow[t]{2}{*}{ All } & \multicolumn{4}{|c|}{ Privatized in } & \multirow[b]{2}{*}{1994} & \multicolumn{2}{|c|}{$\begin{array}{c}\text { Average revenues } \\
\text { (US\$ mil, constant prices) }\end{array}$} & \multicolumn{2}{|c|}{$\begin{array}{l}\text { Average employment } \\
\text { (full-time employees) }\end{array}$} \\
\hline & & 1990 & 1991 & 1992 & 1993 & & 1990 & 1993 & 1990 & 1993 \\
\hline \multicolumn{11}{|l|}{ All countries } \\
\hline State firms & 90 & & & & & & 17.6 & 11.0 & 876 & 573 \\
\hline Outsider-owned firms & 95 & 12 & 16 & 37 & 26 & 4 & 22.5 & 16.2 & 882 & 647 \\
\hline Insider-owned firms & 30 & 1 & 4 & 12 & 10 & 3 & 6.0 & 5.1 & 404 & 325 \\
\hline \multicolumn{11}{|l|}{ Czech Republic } \\
\hline State firms & 23 & & & & & & 22.2 & 13.0 & 1343 & 797 \\
\hline Outsider-owned firms ${ }^{b}$ & 50 & - & 5 & 29 & 15 & 1 & 25.4 & 17.1 & 1203 & 790 \\
\hline Insider-owned firms ${ }^{\mathrm{b}}$ & 6 & - & - & 4 & 2 & - & 9.8 & 5.6 & 725 & 339 \\
\hline \multicolumn{11}{|l|}{ Hungary } \\
\hline State firms & 26 & & & & & & 29.5 & 13.1 & 605 & 416 \\
\hline Outsider-owned firms & 39 & 10 & 7 & 8 & 11 & 3 & 20.7 & 14.6 & 671 & 461 \\
\hline Insider-owned & 24 & 1 & 4 & 8 & 8 & 3 & 5.6 & 5.0 & 376 & 323 \\
\hline \multicolumn{11}{|l|}{ Poland } \\
\hline State firms & 41 & & & & & & 8.0 & 8.6 & 734 & 544 \\
\hline Outsider-owned firms ${ }^{c}$ & 6 & 2 & 4 & - & - & - & - & 19.5 & - & 914 \\
\hline
\end{tabular}

a The sample descriptions given in this and other tables in this appendix pertain to the sample of firms in the growth of revenue regressions.

${ }^{\mathrm{b}}$ In the Czech Republic, the year of privatization refers to the year in which the new owners assumed control rather than the year during which the shares were formally distributed

${ }^{c}$ For Polish privatized firms, the 1990 revenue and employment levels were not provided.

\section{A2: Sectoral distribution of sample firms}

\begin{tabular}{lcrr}
$\begin{array}{c}\text { Industrial sector } \\
\text { (two-digit SIC code) }\end{array}$ & State firms & $\begin{array}{l}\text { Outsider-owned } \\
\text { firms }\end{array}$ & Insider-owned firms \\
\hline Food \& beverages & $18(20 \%)$ & $36(38 \%)$ & $7(23 \%)$ \\
Clothing & $12(13 \%)$ & $9(10 \%)$ & $10(33 \%)$ \\
Furniture & $13(15 \%)$ & $6(6 \%)$ & $3(10 \%)$ \\
Textile & $8(9 \%)$ & $13(14 \%)$ & $4(13 \%)$ \\
Leather & $7(8 \%)$ & $3(3 \%)$ & $3(10 \%)$ \\
Chemicals & $13(14 \%)$ & $8(8 \%)$ & $1(3 \%)$ \\
Non-ferrous minerals & $15(16 \%)$ & $19(20 \%)$ & $2(7 \%)$ \\
Other & $4(4 \%)$ & $1(1 \%)$ & - \\
\hline
\end{tabular}


Why Ownership Matters, page 34

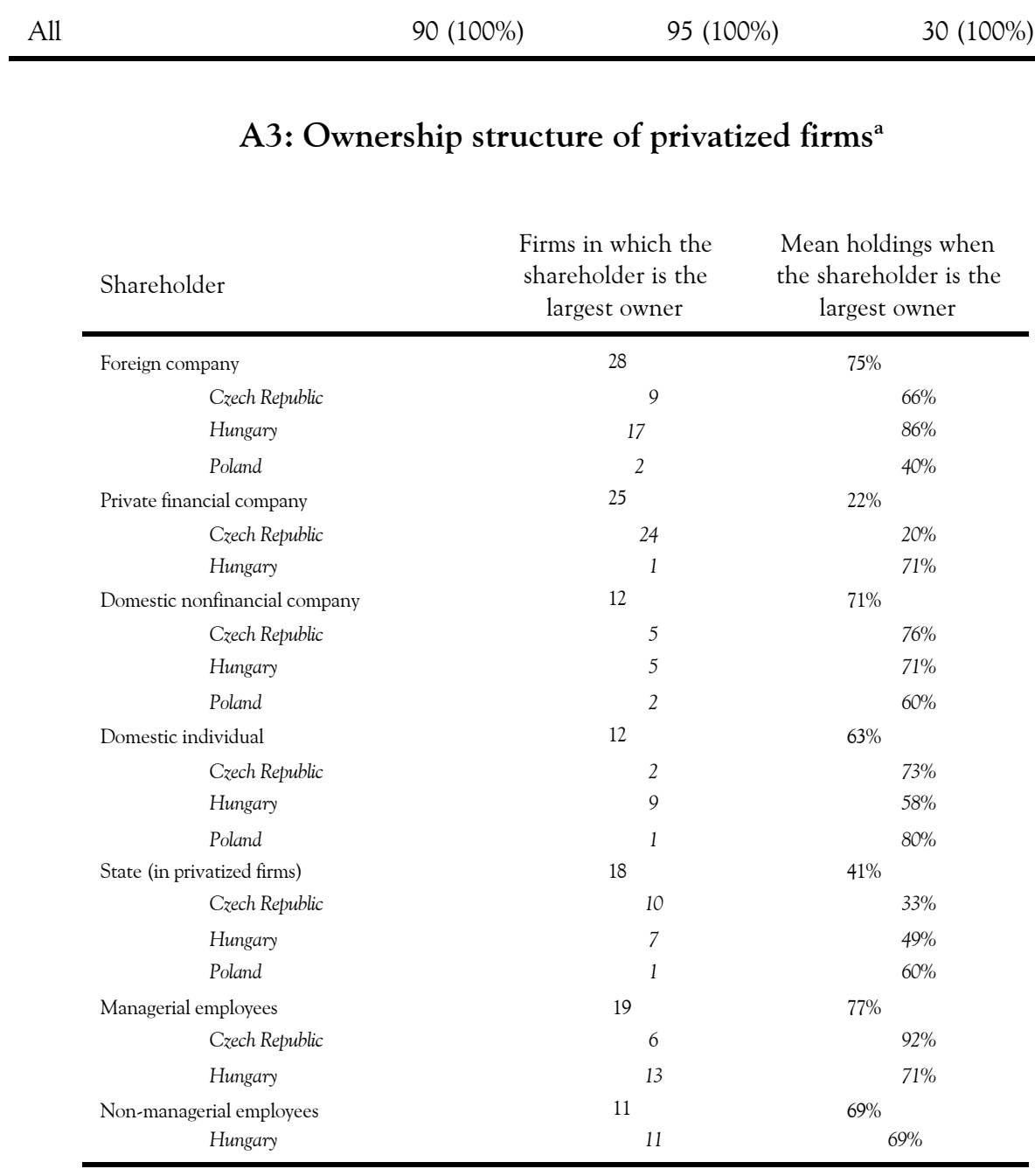




\section{Appendix B: Methodological note on panel regressions}

The main results of this paper are based on regression analyses of revenue and cost performance panel data provided by the sample firms. Although the panel regressions reported in different sections of the paper vary in terms of variables used, the main features of most specifications are common, and we describe them here to avoid unnecessary repetitions.

We use a standard panel data treatment evaluation procedure (Ashenfelter and Card, 1985; Heckman and Holtz, 1989) with the characteristic of interest (e.g., restructuring, managerial change) viewed as the "treatment" variable. ${ }^{27}$ In all regressions, the outcome variable is the annual rate of growth of performance (revenues or costs) of a firm, and the effects of the treatment are controlled for differences in the initial levels of a firm performance as well as the macroeconomic conditions in the three countries.

All panel regressions are fixed effects specifications. Let $i$ index individual firms, $j$ index their ownership grouping (e.g., state or privatized), $k$ index the treatment (e.g., product restructuring, managerial change), and $t$ index time (year). If $\mathrm{y}_{\mathrm{itt}}$ the outcome variable, is the rate of growth of performance measure for firm $i$ between $(t-1)$ and $t$, the following is the group fixed effects specification of performance equations involving comparisons of state and privatized firms:

$$
\mathrm{y}_{\mathrm{ijt}}={ }^{\prime}{ }_{\mathrm{j}}+\left(\mathrm{P}_{\mathrm{ijt}} \times \mathrm{T}_{\mathrm{ikt}}\right) \$_{\mathrm{jk}}+\mathrm{X}_{\mathrm{ijt}-1}\left(+\mathrm{D}_{\mathrm{ct}}{ }_{\mathrm{ct}}+\mathrm{g}_{\mathrm{kt}} .\right.
$$

$\mathrm{P}_{\mathrm{ijt}}$ is the ownership indicator variable equal to 1 if firm $i$ operates as ownership type $j$ firm in period $t$ and 0 otherwise, and $T_{i k t}$ is the treatment variable equal to 1 for post-treatment performance of firm $i$ and 0 otherwise. $\mathrm{X}_{\mathrm{itt}-1}$ is the level of performance at the beginning of the period for which the rate of growth is computed (e.g. if the rate of growth of revenue is computed for 1991-92 period, $X_{\mathrm{itt}-1}$ is the level of revenues for 1991), included to control for differences in the initial conditions (such as firm size or extent of inefficiency), and $D_{c t}$ is a set of country-year dummies controlling for possible differences in the macroeconomic environment of the three countries.

For evaluating the effects of a particular treatment (e.g., product restructuring) within a single ownership group of firms (e.g., state firms only), we restrict the sample to that group of firms and estimate equation (1) with the treatment variable $T_{i j t}$ included and the ownership variable $\mathrm{P}_{\mathrm{ijt}}$ excluded; similarly, for comparisons of the effects of ownership changes among firms with the same treatment, we restrict the sample to firms which either receive or do not receive the treatment and use equation (1) with the ownership variable $\mathrm{P}_{\mathrm{ijt}}$ included and the treatment variable $T_{i j t}$ omitted. (This is equivalent of treating privatization as the only treatment variable.)

Equation (1) specifies fixed effects at the ownership group level. It thus assumes that firms grouped by ownership types have similar distributions of unobservable characteristics that

\footnotetext{
${ }^{27}$ Recent applications of this procedure include the evaluation of the effects of strengthening workers' incentives on productivity in Chinese state-owned enterprises (Groves et al., 1994) and the effects of arrests on employment and earnings of young men (Grogger, 1995).
} 
Why Ownership Matters, page 36

influence performance outcomes, and therefore controls for possible selection bias stemming from nonrandom selection of firms for privatization to particular types of owners. In the firm fixed effects specifications, group fixed effects " ${ }_{j}$ are replaced by firm fixed effects " ${ }_{i}$. The firm fixed effects specification controls for possible selection bias stemming from the fact that firms grouped within a given ownership category may differ among themselves with respect to some unobserved characteristics correlated with performance outcomes.

Except for the predictable consequences of the loss of degrees of freedom associated with the firm fixed effects specification, the two sets estimates were virtually identical in our sample. Inasmuch as in some cases comparisons of pre-treatment performance of state and privatized firms are of interest, we discuss group fixed effects estimates throughout the paper. We do report, however, differences between the two sets of estimates whenever they arise. 